Gender and Education

\title{
Teaching Christine de Pizan in Turkey
}

\section{Sandrine Berges}

To cite this article: Sandrine Berges (2013) Teaching Christine de Pizan in Turkey, Gender and Education, 25:5, 595-604, DOI: 10.1080/09540253.2013.808900

To link to this article: https://doi.org/10.1080/09540253.2013.808900

\section{Published online: 25 Jun 2013.}

Submit your article to this journal ๔

Џll Article views: 161

Citing articles: 2 View citing articles 5 


\title{
Teaching Christine de Pizan in Turkey
}

\author{
Sandrine Berges* \\ Department of Philosophy, Bilkent University, Bilkent, Ankara 06800, Turkey
}

(Received 13 January 2013; final version received 24 March 2013)

\begin{abstract}
An important part of making philosophy as a discipline gender equal is to ensure that female authors are not simply wiped out of the history of philosophy. This has implications for teaching as well as research. In this context, I reflect on my experience of teaching a text by medieval philosopher Christine de Pizan as part of an introductory history of philosophy course taught to Turkish students in law, political science, and international relations. I describe the challenges I encountered, the ways in which I dealt with them, and draw some conclusions based on my observations and feedback obtained at the end of the course.
\end{abstract}

Keywords: feminism; history of philosophy; service course; Turkey; Christine de Pizan

\section{Introduction}

There is a project sometimes referred to as 'the recovery project' and which consists in finding works by women philosophers from history, and making efforts towards ensuring that they are read, studied, and valued in accordance to their philosophical quality. ${ }^{1}$ This has led to a second project that of re-inserting these writers into philosophy courses (Warren 2009, 6). The attempt at teaching a text by a medieval female philosopher described in this article belongs to this second project.

Next week, for the second time round, I will be teaching a class on Christine de Pizan's The City of Ladies, in English, to Turkish students from the law, political science, and international relations departments. This is part of a service course offered by the department of philosophy in a private university in Ankara. The course, entitled 'Introduction to the history of social and political philosophy' has been taught here for over 10 years. It is a course based on the study of classic texts in the history of philosophy, and it has two components: one English language component, taught by an academic English instructor, and a component focussing on the ideas and arguments presented in the texts taught by a teacher from the philosophy department. The classes are small - no more than 25 students per section - and they tend to be gender balanced. The students are, unless they are retaking the course, in their second year, so most of them are aged 19 or 20. The syllabus for the course states that five texts should be read each semester, among which, two required, and three to choose from a number of options. In the first semester, which goes from Ancient Greek thought to the Renaissance, the required texts are Plato's Republic and Aristotle' Ethics or Politics. Optional texts are Thucydides - a selection from the History of the Peloponisian War - Plato's Five Dialogues, John Dillon's Greek

*Email: sandrineberges@gmail.com 
Sophists, Lucretius's On the Nature of Things, Cicero's On Duties, Augustine's Political Writings, Aquinas' Political Writings, and Machiavelli's Selected Political Writings. $^{2}$

Last year, at my request, Christine de Pizan's The Book of the City of Ladies was included to the list of optional texts. This book, written at the beginning of the fifteenth century by a single mother turned professional author, begins with the author's constatation - and resulting discouragement - that women are depicted as incapable of virtue in many philosophical and literary works. She is then visited by three Ladies, visions from heaven, who call themselves Reason, Rectitude, and Justice, who task her with building a literary city for women in which they will be free to flourish according to virtue, and protected from the slanders of men. In order to build the foundations of the city, Christine must ask many probing questions about the project, questions regarding the capacity of women for virtue, wisdom, justice, courage, etc. She must then find virtuous women to populate her city, and plenty of examples are found from mythology, legend, history, and the bible. Because it is a long book, and some of the historical sections are somewhat repetitive, we settled on an abridged version of a translation by Rosalind Brown-Grant (Pizan 2005).

My motivation for suggesting this text was twofold. First, it strikes me as obvious that women's current place in the philosophical profession will not improve unless we make a real effort to re-instate women philosophers into the canon. Female writers who were thought to have made a real contribution to various debates by their peers have, little by little, been weeded out of the taught curriculum so that they now only very rarely feature in history courses, and are no longer part of the general consciousness of the profession. ${ }^{3}$

Second, from a purely pedagogical point of view, it is counter-productive to teach philosophy as something that is only successfully practiced by men - and it is clearly the message that students receive when there are only male names on their reading list. This is poor practice not only from the point of view of forming future philosophers women students will gain less confidence from their history courses, and therefore be less likely to carry on studying at the postgraduate level, and the sometimes slightly aggressive confidence of male students will be re-inforced by the message that as male, they are more likely to succeed - but also in courses taught to non-philosophy majors. Any student faced with an all-male list of 'classic' authors will almost certainly learn to think that only male authors were successful in the past. They might consider the possibility that fewer women had the opportunity to write philosophy, but they will none-the-less be confronted with the hard reality that not a single woman wrote anything good enough to be taught in universities. Such 'knowledge' can only re-inforce existing stereotypes. Women, it seems to say, are now tolerated in most professions, but we must bear in mind that no matter what they do, they will probably not excel in the way that men do. Introducing female authors in the curriculum may help redress this prejudice.

\section{The challenges}

\subsection{Women authors and the canon}

After proposing to the course leader that we should introduce de Pizan to the curriculum, we gathered informal feedback from the other teachers. Among the answers were 'Who is she?', 'Is she a philosopher?', and 'Is she important enough to be on this 
course?' None of these questions constitutes a prima facie sexist response. There is no reason why people, who work predominantly on metaphysics, or philosophy of mind, should have heard of Christine de Pizan. She is not, after all, taught to undergraduate students, and does not form part of anyone's general culture. She is known to people working in the literature, to some historians, to a handful of feminist philosophers, but that is it. This also means that the question 'Should she be on this course' is legitimate. The course is designed to engage students with the great thinkers of the past, teach them to think critically, and at the same time offer them the opportunity to acquire a general philosophical culture. Introducing a minor figure in that mix may not be a good thing. It may in fact prevent the teaching of a text which students really ought to know about.

There are two answers to this objection. The first is that aside from Plato and Aristotle, it does not seem that any of the authors taught in the first part of the course (Lucretius, Cicero, Augustine, Aquinas, and Machiavelli) are in any way essential to the cultural education of a twenty-first century student. They are desirable, but no one will be pass for a cultural fool who has read Plato, Aristotle, Christine de Pizan, but not, say, Aquinas.

The second point is that if we think that female philosophers should be included in university curricula, we must somehow break the circle. Christine de Pizan is unknown because she is not taught. The prejudice that she is therefore not important - and for those who do not know her, it must be a prejudice - can only be combatted if she becomes known. There is a very vicious circle at play here: women's writings are not part of the canon; therefore, they are not taught, which means they remain obscure and are judged non-important, and as a result are refused to enter the canon.

The canon is neither, of course, immutable, nor is it sacred. People go in and out of fashion, often in relation to contemporary research. ${ }^{4}$ Therefore, for example, Aristotle's Ethics is probably taught more often now that virtue-ethics is mainstream, and in particular, that it has become relevant to business and healthcare ethics. Conversely, not many ethics courses require that students read Moore any more. But no matter what angle one looks at it from, women authors do not come in and out of the canon. They remain out.

This is a conundrum that those who want to introduce women into the teaching of history of philosophy too often find themselves in: how can we demonstrate that a woman is a philosopher worthy of being taught along others if these others do not discuss her? This is why female philosophers such as de Pizan and Wollstonecraft often find themselves relegated to other disciplines such as the literature, gender studies, or history. As philosophers, they are simply forgotten.

\subsection{Unfamiliar history}

Convincing one's colleagues that a fairly unknown medieval female philosopher should be included in a course on the history of philosophy is one thing. But in a Western European or North American university, there is at least a chance not only that students will recognise the name Christine de Pizan or that at least they will be familiar with the period of history during which she lived and wrote. It will be enough to mention that she wrote a poem about Joan of Arc to obtain some sort of recognition from the audience. ${ }^{5}$ But this history does not form part of the Turkish general culture, and it is therefore much harder to justify to a Turkish audience that they 
should read the City of Ladies. More work is needed to fill in the background, and to place her in the context of the other authors they are asked to study.

When a text is taught regularly, a certain context comes into being which renders the teaching of historical details less necessary. Therefore, for instance, it is often judged sufficient when introducing Plato to undergraduates to mention his relationship to Socrates and the creation of the Academy, but few of us go into any detail concerning Athenian history. ${ }^{6}$ As far as Augustine is concerned, all we often need to say in a service course is that he was an early Christian that his relationship to his mother was very important to him and that he gave up an immoral lifestyle when he discovered God. Those writers belong to a debate which goes beyond history - we relate them to each other, more than we do to their times (which is not to say that there is no value in the close historical study of their work). In terms of teaching philosophy in Turkey, what this translates to is that it's perfectly possible to introduce the Socratic method or Aritotle's doctrine of the mean to students who in many cases have very little knowledge of Ancient Greece.

The same is not true when it comes to teaching Christine de Pizan. It is difficult to read her text and get anything out of it if we do not discuss a historical context which is not only very obscure to students who know little of Western European history, but also rather complicated - the wars between France and England and the questions of royal succession. But also, much of de Pizan's text is a rewriting of mythology and stories from Boccaccio, a feminist interpretation of stories that her contemporaries were familiar with (Boccaccio 2011). Her account of rape, for instance, is based on the story of Lucretia (Pizan 2005, II, 44, 64), so tinged with political content, her views on women's wisdom, courage, and inventiveness are all based on a retelling of Greek myths such as that of Minerva, an especially wise woman made Goddess by the Greeks who could not bear the idea that a mere woman could surpass men in wisdom (Pizan 2005, I, 34); that of Arachne, the inventor of the art of weaving, so in myth likened to a spider (Pizan 2005, I, 39); that of the Amazons whose strength and courage were only matched by their loyalty, so that they lost to Theseus out of love (Pizan 2005, I, 16-8). ${ }^{7}$ Those feminist retellings of the myths require a certain basic knowledge of them. In practical terms, this means that passages must be carefully selected to match what knowledge of Greek mythology we can expect the twenty-first century students to have, and not to take such knowledge for granted, but always retell the story in class.

Just as it is easy to link Plato to Socrates, and Aristotle to Plato, because they are part of a philosophical history, it is possible to fit the study of de Pizan into an intellectual context suitable for students of an introductory course. I chose to present de Pizan as continuing the tradition of Aristotelian virtue-ethics, a choice based on what de Pizan scholars have to say on the matter (Green 2005). This situates her text in the same area as those of Plato, Aristotle, Cicero, and Aquinas. Another possibility would have been to present her in the same breath as Machiavelli, and have a section of the course dedicated to Mirror of Princes literature. These are not incompatible options by any means.

\subsection{Talking about women rights in a Muslim country}

One question I have encountered, when I have spoken of teaching de Pizan (and indeed Wollstonecraft) in Turkey, is how the idea of a female writer, touching on feminist issues was received in a predominantly Muslim country. This question is in some sense misguided. Turkey is predominantly Muslim in the sense that England is predominantly Christian - it is the state religion, and many people identify themselves as 
Muslim, but this in no way dominates either the intellectual or the cultural life of Turkey.

Turkey also has a strong history of feminism: women were granted the right to vote in 1934, that is, earlier than many places in Europe. ${ }^{8}$ And in the early days of the Republic, they were encouraged to take up professions and other activities that would have been regarded as exclusively male in the Ottoman Empire. ${ }^{9}$ Turkey is no stranger to the idea that gender equality must be fought for. On the other hand, the country did suffer a significant backlash in the sixties, at a time when European and North American women were burning their bras, and, although the feminist spirit never died, it is quite clear that gender equality has not progressed here as far as it should have. ${ }^{10}$ Turkish women are still expected to defer to their husbands and fathers, and those who work typically do all the housework and childcare at home as well. Among the richer sections of the population, to which the private university students I work with tend to belong, inequality is rife, if not in principle, at least in practice. In particular, students have very gendered conceptions of themselves, reflected in their grooming and dress. Women who identify as headscarf wearing Muslims tend, on the whole, to have views more in tune with Western European feminism. This may seem paradoxical, but many of these women wear a headscarf as a result of a late 1980s feminist religious movement, rather than because of very traditional views on religion and the place of women. ${ }^{11}$ Therefore, at least so far as university going, well-off Turks are concerned, it is among the secular, rather than the religious students that we tend to find those who may have difficulties with feminist thought. This explains the particular kind of success I encountered in teaching the course, namely that a lot of female students related well to the sort of feminist struggles in a highly patriarchal world discussed by Christine de Pizan.

\section{The themes}

Often in a service course, especially if, as in this case, it is a must course there is a particular need to arouse the students' interest in the material. After all, they did not choose to study this particular topic, but it was imposed to them by the university administration who judged that their general education required it. This is particularly true in the case of an author they have never heard of, and that they might be tempted to dismiss as the instructor's paltry attempt at political correctness. I decided to tackle this particular problem by focussing on certain questions raised by de Pizan which would allow my students to discuss some very central and very contemporary themes in feminist thought. I present them below, along with a brief discussion of their pedagogical impact.

\subsection{The medieval glass ceiling: women and work}

In Book I, Chapter 11, de Pizan asks her first interlocutor, Lady Reason why there are no women judge or barrister, even though Lady Reason tells her that women are equally capable of the wisdom and justice required for those jobs. Lady Reason replies that these are professions which require not only wisdom and justice, but also a degree of physical strength that men have, but not women. Someone who hands down judgment might be called upon, she says, to enforce it in the face of an accused's recalcitrance. A strong body and a loud voice will ensure obedience. Yet, a little further (Chapters 14ff), Christine de Pizan recounts the exploits of the Amazons, women 
who were not only physically courageous, but had strong bodies. Clearly, she does not believe that women are naturally incapable of developing the kind of strength that she thinks is required for upholding the law.

These passages encourage a reflection on the relationship between force and justice, might and right. Is women's place in the world solely determined by the fact that they are not as physically strong as men? Does the fact that women take exercise make it more likely that they will be regarded as equal? In the second semester, I remind my students of this passage when we read Wollstonecraft's arguments for the physical education of young women. If women are to be equal, she says, they must be allowed to develop their bodies as well as their minds, as good health and strength are essential for living a productive life.

Lady Reason's answer does not merely focus on physical strength but appeals to the idea that we all have a pre-ordained place in society that we should not challenge. Men and women are designed by God to be useful in different ways, and they should therefore find occupations that reflect their usefulness. This does not include, for women, the domain of law. This combination of the desire to show equality on the one hand, but to preserve a certain kind of essentialism which is reflected in social arrangements was familiar to my students because they had read Plato's Republic. We took this opportunity to revisit Plato's view that justice and harmony in the city were only possible if each member of the society stuck to their own specialisation, even if at times it involved some sacrifice on the part of individuals whose ambitions differed from their talent. We asked to what extent such sacrifices could be expected from women merely on the basis of their bodies. I reminded students that de Pizan agrees that women should be excluded from courts of laws, but not that they should not be writers, inventors, rulers, and sometimes even warriors. I also reminded them of Plato's decree that women too should be philosopher rulers, and that their propensity to bear children should no more disqualify them from doing that job than it should disqualify a female guard dog from being useful.

The discussion led, of course, to observations on the evolution of women's place in Turkish legal professions - this was particularly relevant at the time as most of my female students were law students. Thirty per cent of Turkish lawyers and $15 \%$ of judges are currently female (Elveren 2006). This constitutes a sizable improvement over the last 10 years. The proportion of male-to-female law students in my classes was roughly equal. With nothing else to go on, it would seem that the state of legal professions in Turkey is, like many male-dominated professions, pyramid shaped, with less and less women as we reach the top. Reflecting on Lady Reason's physical explanation, which, if it ever was, could not possibly be relevant nowadays, enabled students to ask a number of questions about the place of women in the part of society to which they were hoping one day they would belong.

\subsection{Lying about women to preserve young men's innocence}

In Book II, Chapters 53 and 54, de Pizan counters an argument proposed by Ovid, and by Jean de Meun in the Romance of Rose, that because some women are not virtuous, it is better to portray them as vicious in the literature so as to warn off young men who might be harmed by them (Ovid 2002; Lorris and Meun 2009).

What is done in the interest of the few, but against that of the others is not just, she argues. Public good requires that we take into account the good of the community as a 
whole, and therefore, one is not justified in slandering women in order to protect young men.

The first point of interest in this argument as far as my students were concerned was its potential for developing critical thinking and argument analysis skills. This was an argument they could identify in the text, setting out its premises and conclusion in the way they had been practicing throughout the semester.

The next exercise required the turning upside down of the argument in a very recognisable way: that it goes against the common good to choose to benefit a few at the expense of others is an argument that is sometimes made against positive discrimination. Contrasting de Pizan's argument to this more recent one brings to light the extent to which positive discrimination is only necessary because one must counter centuries of discrimination against women.

One last point I raise in respect to this is Christine de Pizan's question to Lady Rectitude as to why women have not, before her, taken up the pen to reply to slanderous writings against women. The answer echoes something that Lady Reason previously said to the author, namely that each person has a particular role to play in society, and that whereas there have been many women before Christine capable of writing and defending women's virtue, they were busy elsewhere and this particular job had fallen to her. We, of course, compared this appeal to order and role in society to the one discussed in the previous section.

\subsection{A medieval lady on the slut walks}

The last of the three weeks spent of de Pizan focuses on Book II, Chapters 44 and 62, in which Christine highlights the absurdity of the belief that women want to be raped, and proposes that we impose death penalty on rapists. In Chapter 62, she further refutes the proposition that women who dress in a 'provoking' manner thereby 'ask' to be raped. Coquetry, she argues, is a perfectly healthy, normal human disposition and should never be mistaken for an invitation to forced sexual intercourse. In any case, if the church tells us it is a sin, it also tells us that one should not judge any body's conscience from the way they dress, so one should not assume that a prettily dressed woman lacks virtue or is available.

From these arguments, I was able to lead students into a debate of very contemporary relevance. We brought de Pizan's claims to bear on the 'Slut walks' movement, started in Canada the previous year, and at the time already spreading throughout the world. Women in major cities were marching in sometimes very revealing outfits, chanting that they were not available for free sex, and that their choice of clothes did not reflect their desire or willingness to be sexually assaulted. The movement had not then come to Turkey, and not all of my students had heard of it.

This debate was somewhat difficult, perhaps because of a lingering prejudice among a number of my students that women who dress in a certain way are being 'provocative' and if they do not deserve to be raped, at least share in the responsibility of what may happen to them. Shortly before that class, I read in the local news that a professor in Konya - a very conservative city from the point of view of religion - had declared that women wearing low cut tops were partly responsible for the 'unpleasant consequences' which might befall them. ${ }^{12}$ Though this is an extreme point of view that hopefully not many people in Turkey share, it does suggest that Christine de Pizan's arguments are still very much needed. 


\section{Feedback and concluding reflections}

A month after teaching the course with a Christine de Pizan component for the first time, some of my students were assigned to my section for the second part of the course, and together, we carried on ploughing our way through the history of social and political philosophy, from the early moderns to the nineteenth century. Once again, out of five texts, I was able to choose one by a woman philosopher: Mary Woolstonecraft's $A$ Vindication of the Rights of Woman. This was somewhat easier to place in the context of the other texts that of the Enlightenment. We spoke of Wollstonecraft's educational programme or the role played by rationality in men and women's moral development.

At the end of the semester, I asked those of my students who had been with me both semesters to fill in a very simple questionnaire on their experience of reading Christine de Pizan as part of the course.

There were five questions: Did you feel that studying The City of Ladies fitted well with the texts we had studied before (Plato, Aristotle)?

(1) Do you feel that it relates well to the texts we studied in the following semester (Hobbes, Wollstonecraft, Kant, Mill, and Nietzsche)?

(2) Did you enjoy this part of the course?

(3) What, if anything, do you feel you learnt by studying Christine de Pizan?

(4) Do you have any other comments you would like to make about studying Christine de Pizan last semester?

I received a dozen responses, all of which replied to the first question by saying they thought de Pizan's text had little in common with either Plato or Aristotle. On the other hand, they all felt that The City of Ladies was comparable to Wollstonecraft's Vindication of the Rights of Woman (but not to the other texts studied that semester). A handful explained this by saying that while de Pizan and Wollstonecraft speak of woman's condition, the others write about the human condition in general. Several suggested it might be better to teach de Pizan and Wollstonecraft apart from the others, perhaps even in a separate course on feminist thought.

This was, of course, a very disappointing outcome as I had hoped to make my students aware of the continuity of philosophical content between, on the one hand, the ancient virtue ethicists and de Pizan, and on the other hand, between Wollstonecraft and other thinkers of the Enlightenment period. I made every effort to present those texts in the context of the intellectual movements of their time, and not merely as feminist texts. In any case, I had hoped my students would avoid making such a distinction between philosophical writings and feminist philosophical writings.

Another comment I read several times in the responses I received was that Christine de Pizan had an unusual writing style which set her apart from Plato, Aristotle, Hobbes, Kant, Mill, and Nietzsche. I was at a loss to interpret this, given the disparity of the styles of the authors they were comparing her to, and moved to regard it, unfortunately, as another mark of prejudice: de Pizan is a female author, and therefore her style must be different, even if there is no norm to compare it to.

On a much more positive note, all the students who responded said that they enjoyed reading Christine de Pizan. Several noted that they had not heard of her before, and that they feel they would have missed out by not discovering her. There was also a clear consensus that they felt they needed to spend time thinking 
philosophically about feminist issues. All were struck by the very contemporary aspect of the problems raised by de Pizan, and by the rebellious character of her writings when they had assumed that a medieval lady would simply accept her lot.

The one comment which struck me - and pleased me - the most was that of a female student who wrote that she had re-read de Pizan, and later Wollstonecraft, with her mother. She told me they spent hours together discussing the ideas put forward in those texts, and using them to reflect on their own lives - marriage, paternal authority, the need to look beautiful at all times. This comment confirmed, as far as I was concerned, my already firm impression that studying that text encouraged students to question certain aspects of gender relations which they had more or less taken for granted. It is a pity that they failed to note the continuity between the male and female authors that they understand de Pizan's text purely as a feminist one, and not one that has universal interest for humanity as a whole. This was perhaps a function of my teaching the text for the first time, and very much hope that the second time around, starting next week, will prove me right. To this effect, I have tried to emphasise in Plato and Aristotle, those aspects that I want them to recognise in Christine de Pizan. It seems to me a general truth that re-inserting women philosophers in university curricula cannot be done without revising the way other texts are taught. This is what I have done.

\section{Acknowledgements}

I wish to thank two anonymous referees for their insightful comments as well as the audience at the VIIIth International Christine de Pizan Colloquium at which a version of this talk was presented, and in particular Ilse Paakkinen, Karen Green, Mary Ann Case, Zeynep Çeçen, and the conference organiser, Anna Loba.

\section{Notes}

1. See, for instance, Waithe (1987, 1989, 1991 and 1995) and Lopez MacAlister (1989a, 1989b).

2. A complete list with references, and a description of the course is available at www.bilkent.edu.tr/ phil/phil_243.htm.

3. This is discussed in many places, but see in particular, Lopez McAlister (1989a, 1989b) and Ree (2002).

4. In my experience there never was, in fact, a fixed 'canon'; there was rather a certain set of tentative judgments about what had importance and quality. Such judgments are always subject to revision, and in fact they were constantly being revised'. (Searle 1990)

5. The Tale of Joan of Arc, in Blumenfeld-Kosinski and Brownlee (1997).

6. Sometimes, it may even be desirable to take the ideas away from their historical context in order to engage students, see Sakezles (1997).

7. References are to book and chapter of the City of Ladies.

8. French and Italian women got the vote in 1945, Romanians and Portuguese a year later, the Belgium in 1948, and the Swiss not until 1972!

9. Though there were feminist activists even in Ottoman times, see Safarian (2007). One such example, who documents the early feminist movement in Turkey, is the writer Fatma Aliye (1862-1936).

10. See Atasu (2000). The Turkish second wave of feminism came in the eighties, cf. Diner and Toktaş (2010).

11. See Ozgalda (1998)'s excellent book on the topic.

12. Hurriyet Daily News, February 17, 2011. The Turkish government distanced itself from the professor's pronouncement and stated its view that Islamic beliefs do not entail that women are responsible for violence done to them. 


\section{References}

Atasu, E. 2000. The Other Side of the Mountain. Istanbul: Milet.

Blumenfeld-Kosinski, R., and K. Brownlee, eds., trans. 1997. The Selected Writings of Christine de Pizan. New York: Norton.

Boccaccio, G. 2011. On Famous Women. Ithaca, NY: Italica Press.

Diner, C., and Toktaş. 2010. "Waves of Feminism in Turkey." Journal of Balkan and Near Eastern Studies 12 (1): 41-57.

Elveren, D. 2006. "Women, Law, and Judicial Decision Making in Turkey." Second World Congress for Middle Eastern Studies, UNESCO, July 2006, pp. 10-11. http://www. unesco.org/new/fileadmin/MULTIMEDIA/HQ/SHS/pdf/gender_justice.pdf

Green, K. 2005. "On Translating Christine de Pizan as a Philosopher." In Healing the Body Politic: The Political Thought of Christine de Pizan, edited by Karen Geen and Constant J. Mews, 117-137. Turnhout, Belgium: Brepols.

Lopez McAlister, L. 1989a. "Special Issue on the History of Women in Philosophy." Hypatia 4 (1): $1-5$.

Lopez McAlister, L. 1989b. "Some Remarks on Explaining the History of Women in Philosophy." Hypatia 4 (1): 1-6.

Lorris, G., and J. Meun. 2009. The Romance of the Rose. Oxford: Oxford World Classic.

Ovid. 2002. The Art of Love. New York: Modern Library.

Ozgalda, E. 1998. The Veiling Issue: Official Secularism and Popular Islam in Modern Turkey. London: Curzon.

de Pizan, C. 2005. The City of Ladies, extract. Translated by Rosalind Brown-Grant, 1999. Penguin Books, Great Ideas.

Ree, J. 2002. "Women Philosophers and the Canon." British Journal for the History of Philosophy 10 (4): 641-652.

Safarian, A. 2007. "On the History of Turkish Feminism." Iran and the Caucasus 11 (1): 141151.

Sakezles, P. K. 1997. "Bringing Ancient Philosophy to Life: Teaching Aristotelian and Stoic Theories of Responsibility." Teaching Philosophy 20 (1): 1-17.

Searle, J. 1990. "The Storm over the University." The New York Review of Books, December 6, 1990.

Waithe, M. E. 1987, 1989, 1991 and 1995. A History of Women Philosophers. 1-4 vols. Netherlands: Kluwer.

Warren, K. 2009. An Unconventional History of Western Philosophy, Conversations between Men and Women Philosophers. Lanham, MD: Rowman and Littlefield. 